Rafał Ogórek, C, Katarzyna Guz-Regner, Tomasz Kokurewicz, Elżbieta Baraniok, and Bartosz Kozak. Airborne bacteria cultivated from underground hibernation sites in the Nietoperek bat reserve (Poland). Journal of Cave and Karst Studies, v. 80, no. 4, p. 161-171. DOI:10.4311/2017MB0117

\title{
AIRBORNE BACTERIA CULTIVATED FROM UNDERGROUND HIBERNATION SITES IN THE NIETOPEREK BAT RESERVE (POLAND)
}

\author{
Rafał Ogórek1, c Katarzyna Guz-Regner², Tomasz Kokurewicz³, Elżbieta Baraniok , Bartosz Kozak
}

\begin{abstract}
The study is the first report of cultivable bacteria present in the close vicinity of hibernating bats. Samples were collected in January 2016 in one location outside the hibernation site and in five locations underground. Samples were incubated at 7 and $37^{\circ} \mathrm{C}$. Bacteria were identified based on phenotypic tests and 16S rRNA gene analysis. Air samples collected inside of underground sites contained more propagules of bacteria (from $232 \pm 28.3$ to $1189 \pm 124.7$ bacterial colony-forming units per $\mathrm{m}^{3}$ of air) than outdoor air samples (42 \pm 12.2$)$. In total, eight species of airborne bacteria belonging to three phyla and three orders were cultured from the samples. More species of airborne bacteria, eight, were isolated from the indoor underground air samples than from the outdoor air, two, especially in close vicinity to hibernating bats. Generally, Actinobacteria dominated in this study. Paeniglutamicibacter psychrophenolicus was isolated most frequently from samples incubated at $7^{\circ} \mathrm{C}$, and Micrococcus luteus from samples incubated at $37^{\circ} \mathrm{C}$. Additionally, the study was supplemented by detailed phenotypic and physiological characteristics of airborne bacteria obtained in the Nietoperek bat reserve.
\end{abstract}

\section{Introduction}

Microorganisms, especially extremophilic Bacteria and Archaea, are able to colonize all niches of the biosphere, including underground ecosystems (Rampelotto, 2013). However, because of low constant temperatures and high humidity of the air, little availability of nutrients, no light, and extensive areas of mineral surfaces, underground ecosystems are one of the most inhospitable habitats for microbial life (Jurado et al., 2010; Vanderwolf et al., 2013; Ogórek et al., 2014). Specific microclimatic conditions in underground sites, especially low temperatures (ca. from $2{ }^{\circ} \mathrm{C}$ to $10^{\circ} \mathrm{C}$ ) and high relative humidity (above $80 \%$ ) of air, allow bats to minimize energy during hibernation, when their food supply is scarce from late autumn to early spring (Speakman and Racey, 1989; Kokurewicz, 2004).

From August to October, before hibernation starts, bats gather in underground sites and actively fly in front of entrances to the underground. This phenomenon, known as swarming, involves circling both inside and outside the hibernacula (Fenton, 1969; Kretzschmar and Heinz, 1995). Due to their unique lifestyle, bats can provide organic nutrients and microorganisms for caves and other subterranean habitats directly from the surface of their bodies or indirectly through their guano. In addition, bat carcasses can be a source of organic matter for bacteria and fungi and a food source for arthropods (Veikkolainen et al., 2014; Kokurewicz et al., 2016; Ogórek et al., 2016a). However, it should be mentioned that other factors such as air currents, percolation via surface water, soil, and sediments, human activities, and the presence of small mammals and arthropods may also influence underground ecosystems and provide energy sources and nutrients (Chelius et al., 2009; Vanderwolf et al., 2013; Ogórek et al., 2016b).

The majority of microorganisms cannot actively grow in the subterranean ecosystems, but they could be present in aerosol form (Ogórek et al., 2016b). Bioaerosols may contain bacteria, fungi, viruses, cellular fragments, fungal spores, and byproducts of microbial metabolism such as mycotoxins, endotoxins, enterotoxins, and enzymes (Mandal and Brandl, 2011). Many reports have been published about underground airborne bacteria and fungi (Rdzanek et al., 2015; Ogórek et al., 2016a, 2016b), but only one microbiological study has been published for a large bat-hibernation site that relates to airborne fungi. It was found that the number of cultivable airborne fungi increase significantly during the hibernation season (Kokurewicz et al., 2016). There are no known similar reports regarding bacteria or bacteria and fungi in bioaerosols a short distance from hibernating bats.

The aims of the study were to determine phenotypic and genotypic diversity of airborne bacteria present close to hibernating bats, to quantify their concentrations, and to assess the pathogenic potential for bat assemblages and in the underground system of Nietoperek bat reserve.

\footnotetext{
${ }^{1}$ University of Wroclaw, Institute of Genetics and Microbiology, Department of Genetics, Przybyszewskiego Street 63/77, 51-148 Wroclaw, Poland ${ }^{2}$ University of Wroclaw, Institute of Genetics and Microbiology, Department of Microbiology, Przybyszewskiego Street 63/77, 51-148 Wroclaw, Poland

${ }^{3}$ Wrocław University of Environmental and Life Sciences, Institute of Biology, Department of Vertebrate Ecology and Paleontology, Kożuchowska 5b, 51-631 Wroclaw, Poland

${ }^{4}$ Wrocław University of Environmental and Life Sciences, Department of Genetics, Plant Breeding and Seed Production, Grunwaldzki Square 24a, 50-363 Wroclaw, Poland

cCorresponding author: rafal-ogorek@wp.pl
} 


\section{Material and methods}

\section{Description of the Study Area}

Nietoperek bat reserve is situated in western Poland in the central part of the so-called Międzyrzecz Fortified Front $\left(52^{\circ} 25^{\prime} \mathrm{N}, 15^{\circ} 32^{\prime} \mathrm{E}\right)$, which was built by Germans in the 1930 s and during World War II. The above-ground bunkers are connected by approximately $32 \mathrm{~km}$ long systems of underground railway tunnels (Woźniak, 1996). To protect hibernating bats and their foraging areas around the fortifications the underground system with the surrounding surface area of 7377.37 ha became protected in November 2007 as Natura 2000 site (area code: PLH080003). The underground corridors of the MMF are one of the ten largest bat hibernation sites in the European Union, and most parts are closed for visitors during the hibernation period from October 15 to April 15. Four bat species are under protection in MMF and mentioned in Annex II of the EU Habitat Directive (Directive 92/43/EEC, 1992) (i.e., Myotis myotis, Barbastella barbastellus, Myotis dasycneme, and Myotis bechsteinii). The air temperature in the underground complex ranges from 0 ${ }^{\circ} \mathrm{C}$ near the entrances to $10.4{ }^{\circ} \mathrm{C}$ in rear parts. So far 12 bat species with a maximum number of 38,594 individuals have been found hibernating there. Since 1995 the dominant species has been the greater mouse-eared bat (M. myotis), constantly increasing in its number since 1985 (Kokurewicz et al., 2014, 2016). Generally, the population of bats in the Nietoperek bat reserve is fairly constant. For example, in January 2014 among all the locations of our study (Fig. 1), the largest number of bats (423 bats) was recorded in section 7.2 (Locations from IV to VI). On the other hand, in Location III there were recorded only several individuals, and in Location II (section 7.8) only ten bats (Kokurewicz et al., 2016).

\section{Sampling Methods}

The observations were made under the license nr.WPN-I.640 I.369.2015.JK issued by Nature Conservancy Management in Gorzów Wielkopolski. The microbial air sampler MAS100-ECO (MBV), and YPG medium (yeast extract peptone glucose: $10.0 \mathrm{~g} \mathrm{~L}^{-1}$ yeast extract, $20.0 \mathrm{~g} \mathrm{~L}^{-1}$ peptone, $20.0 \mathrm{~g} \mathrm{~L}^{-1}$ glucose, $15.0 \mathrm{~g} \mathrm{~L}^{-1}$ agar) were used for the microbiological evaluation of the air. In order to eliminate fungi and yeast from the bacteria samples, $30 \mathrm{~g} \mathrm{~mL}^{-1}$ of nystatin was added to the medium (Polfa, Kraków). The samples were taken on January 9, 2016 from one location situated ca. $5 \mathrm{~m}$ in front of the entrance of the underground tunnels of Nietoperek bat reserve and from five locations inside of them (Fig. 1). The microbial air sampler was positioned at a distance of $0.7 \mathrm{~m}$ from clusters of $M$. myotis (locations from IV to VII) or it was positioned $1.5 \mathrm{~m}$ above the level of the floor (locations from I to III). It was programmed for air sample volumes of $50 \mathrm{~L}$ and $100 \mathrm{~L}$, and the measurement in particular sampling sites was performed in triplicates for each volume. The incubation of samples in Petri dishes with YPG medium was carried out at $7 \pm 0.5^{\circ} \mathrm{C}$ for 21 days and 37 $\pm 0.5^{\circ} \mathrm{C}$ for 5 days. After incubation, bacterial colonies on the plates were counted, and the colony-forming units concentrations were expressed as CFU per cubic meter of air using the formula $X=(a \times 1000) / V$, where $a$ is the number of colonies obtained on a Petri dish, and $V$ is the air volume sampled $\left(\mathrm{m}^{3}\right)$. Then bacterial colonies were subcultured on YPG medium for phenotypic and molecular identification.

\section{Phenotypic Studies}

Bacterial colonies on YPG medium were subcultured on nonselective media, Nutrient agar (NA, Biocorp, Poland) and Tryptic Soy agar (TSA, Biocorp, Poland) for morphological and phenotypic analyses. Biochemical and enzymatic characteristics of bacterial isolates were determined after incubation at $25 \pm 0.5^{\circ} \mathrm{C}$ for $48 \mathrm{~h}$ by using commercial systems API 20NE and API 20 Staph (Biomerieux) with inoculation of $0.5 \mathrm{McF}\left(10^{8} \mathrm{CFU} \mathrm{ml}{ }^{-1}\right)$ in sterile water solution of $0.85 \% \mathrm{NaCl}$. The profile of substrate utilization by bacteria in oxidative and fermentative conditions was assessed according to recommended procedures using API Aux Medium (1.5\% v/v vitamin solution, $1 \% \mathrm{v} / \mathrm{v}$ trace elements, $0.15 \%$ agar, $\left.0.2 \%\left(\mathrm{NH}_{4}\right)_{2} \mathrm{SO}_{4}, 0.62 \% \mathrm{NaH}_{2} \mathrm{PO}_{4}, 0.15 \% \mathrm{KCl}\right)$ and API Staph Medium $(0.05 \%$ yeast extract, $1 \%$ bactopeptone, $0.5 \% \mathrm{NaCl}$, trace elements $1 \% \mathrm{v} / \mathrm{v})$. The addition of reagents and the interpretation of reactions were done according to the manufacturer's directions. The supplementary tests, including those for cell morphology and Gram-stain reaction, oxidase and catalase production, and casein, starch, and Tween-80 utilization were performed based on standard methods (Smibert and Krieg, 1994). The ability of growth for bacteria $\left(C_{\mathrm{k}} 10^{4} \mathrm{CFU} \mathrm{mL}{ }^{-1}\right)$ at $25 \pm 0.5^{\circ} \mathrm{C}$ and $35 \pm 0.5^{\circ} \mathrm{C}$ and in the presence of $12.5 \% \mathrm{NaCl}$ at $25 \pm 0.5^{\circ} \mathrm{C}$ was evaluated visually based on the turbidity of Nutrient Broth (NB, Biocorp, Poland) after incubation for 1 to 3 days. The antimicrobial susceptibility to bacitracin (10UI, Becton Dickinson, Poland) and furazolidone (100 mg L-1. Becton Dickinson, Poland) was determined after incubation at $25 \pm 0.5^{\circ} \mathrm{C}$ for $24 \mathrm{~h}$ to $48 \mathrm{~h}$ by disc diffusion test on nutrient agar with bacterial suspensions of $0.1 \mathrm{~mL} 10^{8} \mathrm{CFU} \mathrm{mL}{ }^{-1}$ in saline water solution of $0.85 \% \mathrm{NaCl}$. Bacterial isolates without a zone of inhibition were defined as resistant. The ability of $\mathrm{N}_{2}$ fixation by bacteria was detected in culture after incubation at $25^{\circ} \mathrm{C}$ for 3 to 5 days by using a modified Ashby (ASH) medium ( $1 \%$ mannitol, $0.5 \%$ terhalose, $0.5 \%$ glucose, $0.02 \% \mathrm{~K}_{2} \mathrm{HPO}_{4}, 0.02 \% \mathrm{Mg}_{2} \mathrm{SO}_{4} \cdot 7 \mathrm{H}_{2} \mathrm{O}, 0.02 \% \mathrm{NaCl}, 0.01 \% \mathrm{~K}_{2} \mathrm{SO}_{4}$, $0.05 \% \mathrm{CaCO}_{3}, 1.5 \%$ agar) (Stella and Suhaimi, 2010). The growth of bacteria on this medium indicated the bacterial ability to fix $\mathrm{N}_{2}$ from the air. The results were interpreted using the APlweb software and monographs (Lapage et al., 1968; Kocur et al., 1972, 1975; Kodama et al., 1985; Margesin et al., 2004; Gupta et al., 2004; Lalucat et al., 2006; Zhao 


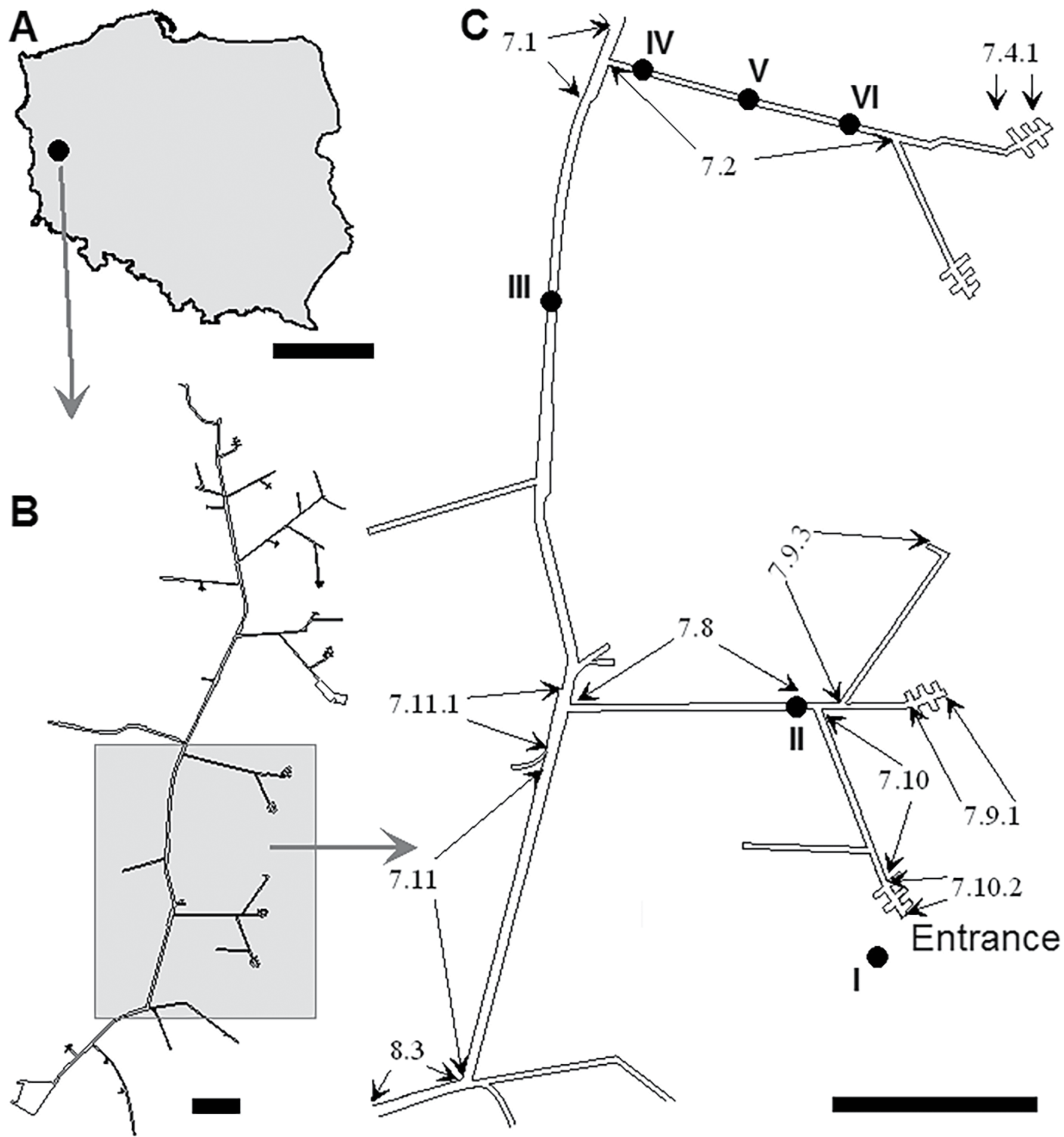

Figure 1. Geographic location of Nietoperek bat reserve in Western Poland (A). The outline of the underground fortification system (B). Sections (7.1-8.3) and sampling sites $(C)$ : location I outside the underground fortification system, and locations II to VI inside the underground fortification system. Scale bars: $A=250 \mathrm{~km}, B$ and $C=500 \mathrm{~m}$.

et al., 2009; Pindi et al., 2010; Kim et al., 2016). Subsequently, bacterial cultures were genetically analyzed to confirm the affiliation of the species and determine the genetic diversity.

\section{Molecular Studies}

DNA was extracted according to the CTAB method (Doyle and Doyle, 1987) with minor modifications (Ogórek et al., 2012). Amplification of DNA was performed in a $25 \mu \mathrm{L}$ reaction mixture using the $2 \times P C R$ mixture containing a Taq polymerase $\left(0.1 \cup \mu \mathrm{L}^{-1}\right)$, dNTP $\operatorname{mix}(2 \mathrm{mM}), \mathrm{MgCl}_{2}(4 \mathrm{mM}), 0.25 \mu \mathrm{M}$ of each primer, rD1: AAGGAGGTGATCCAGCC, 
and fD1: AGAGTTTGATCCTGGCTCAG (Weisburg et al., 1991) and $45 \mathrm{ng}$ of DNA in the Biometra thermal cycler for 35 cycles. After initial denaturation for 5 min at $94^{\circ} \mathrm{C}$, each cycle comprised $30 \mathrm{~s}$ denaturation at $94^{\circ} \mathrm{C}, 30 \mathrm{~s}$ annealing at $55{ }^{\circ} \mathrm{C}, 45 \mathrm{~s}$ extension at $72{ }^{\circ} \mathrm{C}$, with a final extension for $7 \mathrm{~min}$ at $72{ }^{\circ} \mathrm{C}$ at the end of $35 \mathrm{cycles}$. The amplification product was separated on agarose gel $(1.5 \%)$, visualized by UV light, purified from the gel and sequenced by the sequencing service at Macrogen (http://dna.macrogen.com/eng/). Partial sequences were analyzed with the BLAST algorithm (http://www.ncbi.nlm.nih.gov/), aligned and compared with published 16s rRNA sequences from GenBank of the National Center for Biotechnology Information, Bethesda, MD, USA.

\section{Results}

Eight species of airborne bacteria belonging to three phyla and three orders were isolated from air samples collected in the Nietoperek bat reserve. The species diversity, eight, of airborne bacteria was higher in air samples collected inside the underground Nietoperek bat reserve than from the outdoor air, two. From indoor and outdoor sites, bacterial species such as Paeniglutamicibacter psychrophenolicus and $P$. sulfurous were cultured only from samples incubated at $7{ }^{\circ} \mathrm{C}$. Other bacterial species were cultured only from samples incubated at $37^{\circ} \mathrm{C}$ (Tables 1,2$)$.

Table 1. Airborne bacteria cultured from air samples in the Nietoperek bat reserve, and results of BLAST analysis (all E values were zero).

\begin{tabular}{|c|c|c|c|c|c|}
\hline \multirow[b]{2}{*}{ Isolate } & \multicolumn{2}{|c|}{ Identification } & \multicolumn{3}{|c|}{ Identity with Sequence from GenBank } \\
\hline & Species & GenBank Accession No. & Query Cover, \% & Identity, \% & Accession \\
\hline UWR_Bak5 & Dermacoccus nishinomiyaensis & KY575239.1 & 100 & 93 & NR_044872.1 \\
\hline UWR_Bak7 & Micrococcus luteus & KY575241.1 & 98 & 91 & KY317958.1 \\
\hline UWR_Bak4 & Micrococcus yunnanensis & KY575238.1 & 98 & 94 & KU877632.1 \\
\hline UWR_Bak8 & Paenibacillus polymyxa & KY575242.1 & 98 & 95 & СР011420.1 \\
\hline UWR_Bak1 & Paeniglutamicibacter psychrophenolicus & KY575235.1 & 100 & 94 & NR_027226.1 \\
\hline UWR_Bak2 & Paeniglutamicibacter sulfureus & KY575236.1 & 96 & 92 & AB046358.1 \\
\hline UWR_Bak6 & Pseudomonas oryzihabitans & KY575240.1 & 100 & 91 & LC191548.1 \\
\hline UWR_Bak3 & Pseudomonas stutzeri & KY575237.1 & 91 & 91 & СР011854.1 \\
\hline
\end{tabular}

Overall, indoor air samples contained more propagules of bacteria than outdoor air samples, from $232 \pm 28.3$ to $1189 \pm 124.7$ and $42 \pm 12.2$ bacterial CFU per $\mathrm{m}^{3}$ of air respectively. The highest number of species isolated from the indoor air was noted for location $\mathrm{V}$ (eight bacterial species) and the smallest number of species was noted for location II (four bacterial species). The incubation temperature of samples influenced the number of bacteria cultured from the air (Table 2). After an incubation of samples at $7{ }^{\circ} \mathrm{C}$, the highest number of detected species was noted for location $\mathrm{VI}$ (Fig. 2). The bacterial species most frequently isolated from the air outside the Nietoperek bat reserve was $P$. psychrophenolicus, and from the air inside of it was Micrococcus luteus (Table 2).

Airborne bacteria isolated from the Nietoperek tunnels showed morphological diversification between the genus, but not within the genus, with the exception of color and colony diameter on nutrient agar medium for Micrococcus and Pseudomonas spp. All species grew at $25^{\circ} \mathrm{C}$ and were resistant to furazolidone. Paenibacillus polymyxa, Pseudomonas oryzihabitans and $P$. stutzeri were also resistant to bacitracin, all other bacterial species were sensitive to it. Species $P$. psychrophenolicus and $P$. sulfureus did not grow at $35^{\circ} \mathrm{C}$, but others did. Among all tested species, only $M$. luteus showed growth in nutrient broth medium with $12.5 \% \mathrm{NaCl}$. The majority of bacteria required oxygen for growth, with the exception of $P$. polymyxa, which grew in presence and absence of oxygen (Table 3).

The studied biochemical properties of airborne bacteria were diversified, although some trends between species belonging to the same genus were detected. Generally, species were separated into two main clusters. Based on enzymatic metabolism, isolates of $P$. psychrophenolicus and $P$. sulfureus showed the highest similarity, and they differed only in reduction of nitrate to nitrite, utilization of glucose, and phenylacetic acid (Table 4). The most extensive biochemical profile showed $P$. polymyxa, and only this species produced acetylmethylcarbinol, $\beta$-glactosidase, $\beta$-glucosidase, and utilized lactose and $\mathrm{N}$-acetyl- $\beta$-glucosamine. In contrast, the narrowest range of biochemical abilities was shown by Dermacoccus nishinomiyaensis. Among all tested biochemical properties, calatase was produced by all tested species, whereas indole was produced by none (Table 4).

\section{Discussion}

Bats (order Chiroptera) occur on all continents except Antarctica. Some species inhabit polar regions and isolated oceanic islands (Jones et al., 2009). These small endothermic mammals play important roles in ecosystems and the economy, as plant pollinators, seed dispersers responsible for regeneration of tropical rain forest, predators of insect 


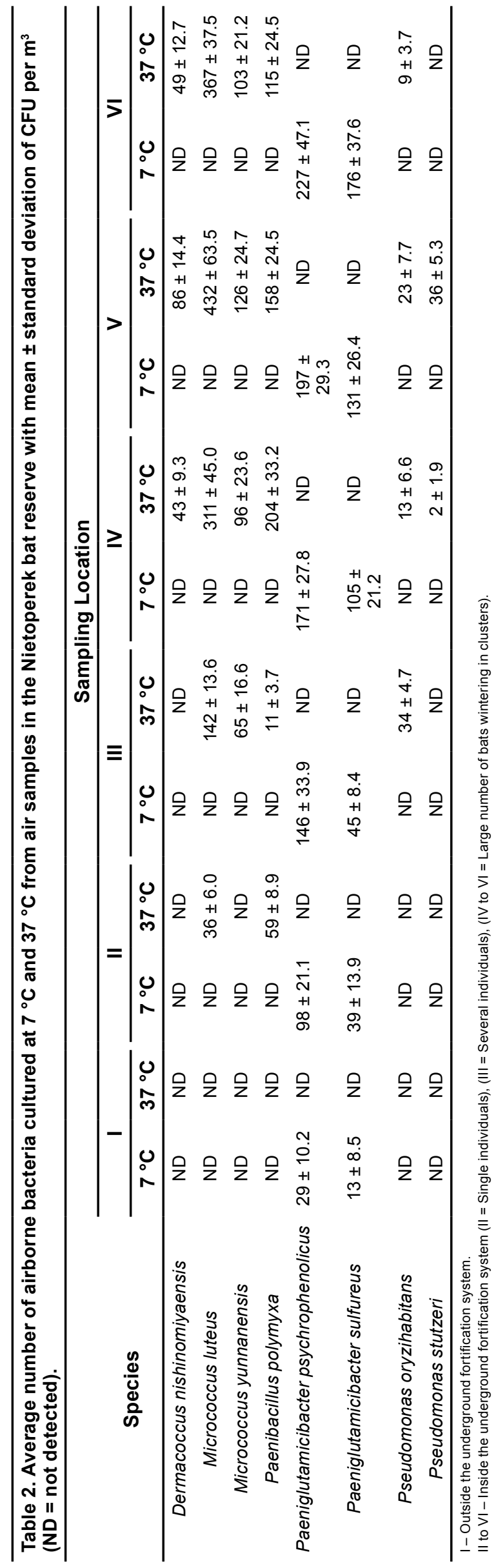

populations, including agricultural and forest pests, and insects harmful for humans such as mosquitoes (Culicidae) and biting midges (Ceratopogonidae and Simuliidae) (Vilas, 2016). Moreover, most bat species are listed in the IUCN Red list of endangered species and almost half of these are considered threatened or near-threatened (Mickleburgh et al., 2002). Thus, their health and factors determining their favorable conservation status should be monitored, including microbial agents that can cause death in bats (Evans et al., 2009; Mühldorfer et al., 2010). Therefore, microbiological monitoring of bats could be a vital element of the protection of these mammals.

Most of airborne bacterial species isolated a short distance from bats hibernating in the Nietoperek belonged to the Actinobacteria phylum. This phylum is widely distributed in the environment and represents one of the largest taxonomic units; it includes five subclasses and fourteen suborders. Actinobacteria are also one of the most dominant groups of the skin microbiota in humans, various amphibian species, fish, and bats (Larsen et al., 2013; Kueneman et al., 2014; Hamm et al., 2017). Members of this phylum are well adapted to survive long periods and grow well in nutrient-depleted environments (Barton et al., 2004). Therefore, Actinobacteria represent one of the most abundant microbiota from the underground ecosystems where bats hibernate (Northup et al., 2011). However, it should be noted that only fewer than $1 \%$ of bacteria from this phylum can be detected by using culture-based methods (Zang et al., 2013). This study supports literature reports that Actinobacteria exhibit a wide variety of morphologies as well as diverse physiological and metabolic properties, such as the production of enzymes (Ventura et al., 2007). Other species of airborne bacteria isolated from the Nietoperek belonged to the Firmicutes and Proteobacteria. These phyla are the cosmopolitan group of environmental bacteria, especially in the colder parts of the world (Teixeira et al., 2010). Firmicutes and Proteobacteria, like Actinobacteria, can colonize the body of bats and their guano, but they are less dominant than the Actinobacteria phylum (Hoyt et al., 2015; Banskar et al., 2016). Some species of Proteobacteria probably play an important role in maintaining interactions in microbial communities of the skin of bats, decreasing or preventing development and growth of undesirable or pathogenic microbes. For example, Pseudomonas spp. isolated from the skin of bats can inhibit in vitro the growth of the whitenose syndrome fungus Pseudogymnoascus destructans (Hoyt et al., 2015).

The study was conducted during winter, and the bacterial species most frequently isolated from the air samples incubated at $7{ }^{\circ} \mathrm{C}$ was Paeniglutamicibacter psychrophenolicus (basonym: Arthrobacter psychrophenolicus), which is a Gram-positive, non-endospore-forming, non-motile aerobic bacterium (Margesin et al., 2004). $P$. psychrophenolicus belongs to the Actinobacteria phylum and cannot grow at temperatures of $35^{\circ} \mathrm{C}$ because 


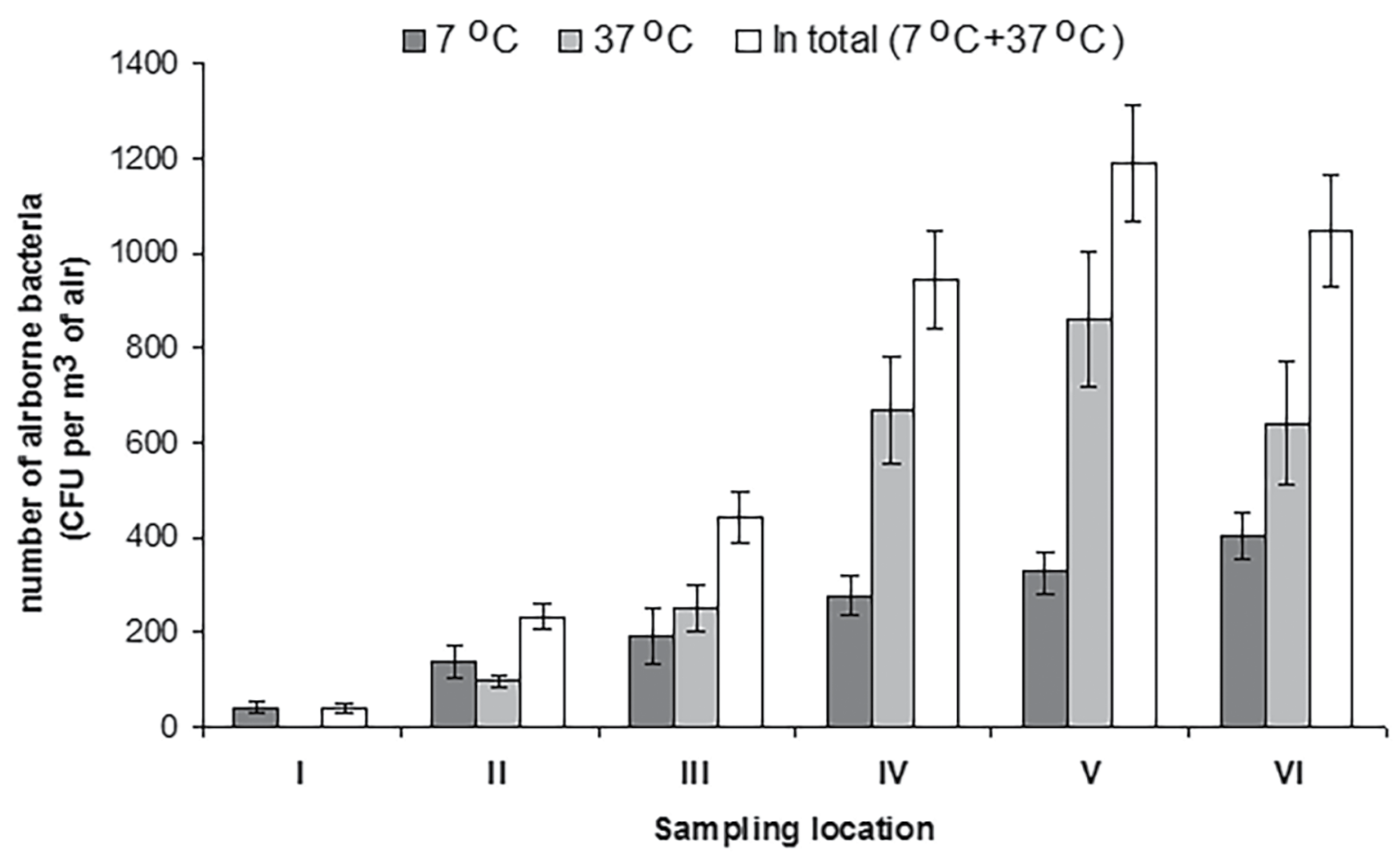

Figure 2. Total number of airborne bacteria (CFU per $\mathrm{m}^{3} \pm$ standard deviation) cultured from the Nietoperek bat reserve. Sampling location I was outside the underground fortification system, locations II to VI were inside the underground fortification system (Figure 1). II had single individuals, III had several individuals, and IV-VI had large numbers of bats wintering in clusters.

of its facultative psychrophilic characteristics (Margesin et al., 2004; Ventura et al., 2007). Cold-adapted species belonging to this genus are widespread among bacteria found in subterranean sites, glacier silts, or Arctic and Antarctic environments (Loveland-Curtze et al., 1999; Juck et al., 2000; Stibor et al., 2003). The ability of $P$. psychrophenolicus and $P$. sulfureus to survive in colder temperatures is probably one of the main reasons that these bacterial species were isolated only from the outdoor air samples in this study.

Of particular interest in this study are phenotypic characteristics and the role of Micrococcus luteus, because it was the most-isolated species from the air samples incubated at $37^{\circ} \mathrm{C}$. M. luteus, in contrast to P. psychrophenolicus, grows at $35{ }^{\circ} \mathrm{C}$ and is a typical Gram-positive, obligate-aerobic bacterium. This species is present in soil, water, and undergrade environments and on the skin of humans and other animals (Kocur et al. 1972; Ventura et al., 2007; Rdzanek et al., 2015). Generally, M. luteus is considered a non-pathogenic saprophyte, but some strains may occasionally act as opportunists. For example, this species can cause septic arthritis, pneumonia, urinary tract infection in an immune-deficient person, meningitis, and native and prosthetic valve endocarditis (Kocur et al., 1972; Fosse et al., 1985).

Other bacterial species isolated from the air a short distance from hibernating bats are mainly considered as saprophytic organisms, but in some situations can be pathogenic. For example, Dermacoccus nishinomiyaensis is found in water and on the skin of mammals and is considered to be non-pathogenic (Kocur et al., 1975). However, according to recent reports, this species can cause wound infections (Shah et al., 2015). Generally, Pseudomonas oryzihabitans is described as a saprophyte of humans and other warm blooded animals (Giacometti et al., 1998; Molinari et al., 2003). In recent years, a nosocomial pathogenic potential has been discussed, because infections usually occur in cases referring to contaminated catheters, peritoneal dialysis, bacteremia, or even sepsis patients (Lucas et al., 1994; Verhasselt et al., 1995; Marín et al., 2000). Thus, P. oryzihabitans infection is strongly associated with presence of bacterial biofilms, previous trauma or surgery, and immunocompromised hosts. Reports of its pathogenic potential in humans are rare (Lin et al., 1997). Micrococcus yunnanensis is a novel actinobacterium that was isolated from surface-sterilized plants (Zhao et al., 2009). It is likely that it is an endophytic bacterium, which naturally colonizes the internal tissue of plants (Pisarska and Pietr, 2015). Paenibacillus polymyxa, formerly known as Bacillus polymyxa, is a plant growth promoting rhizobacterium that is used for the biocontrol of plant diseases (Ash et al., 1993; Dijksterhuis et al, 1999). For example, it is used against the plant-parasitic nematodes, and phytopathogenic fungi (Caruso et al., 1984). Additionally, this species is antagonistic to human pathogenic bacteria and fungi in vitro (Seldin et al., 1999). Pseudomonas stutzeri is a typical soil bacterium that is widely distributed in the environment (Lalucat et al., 2006). It can be an opportunistic 


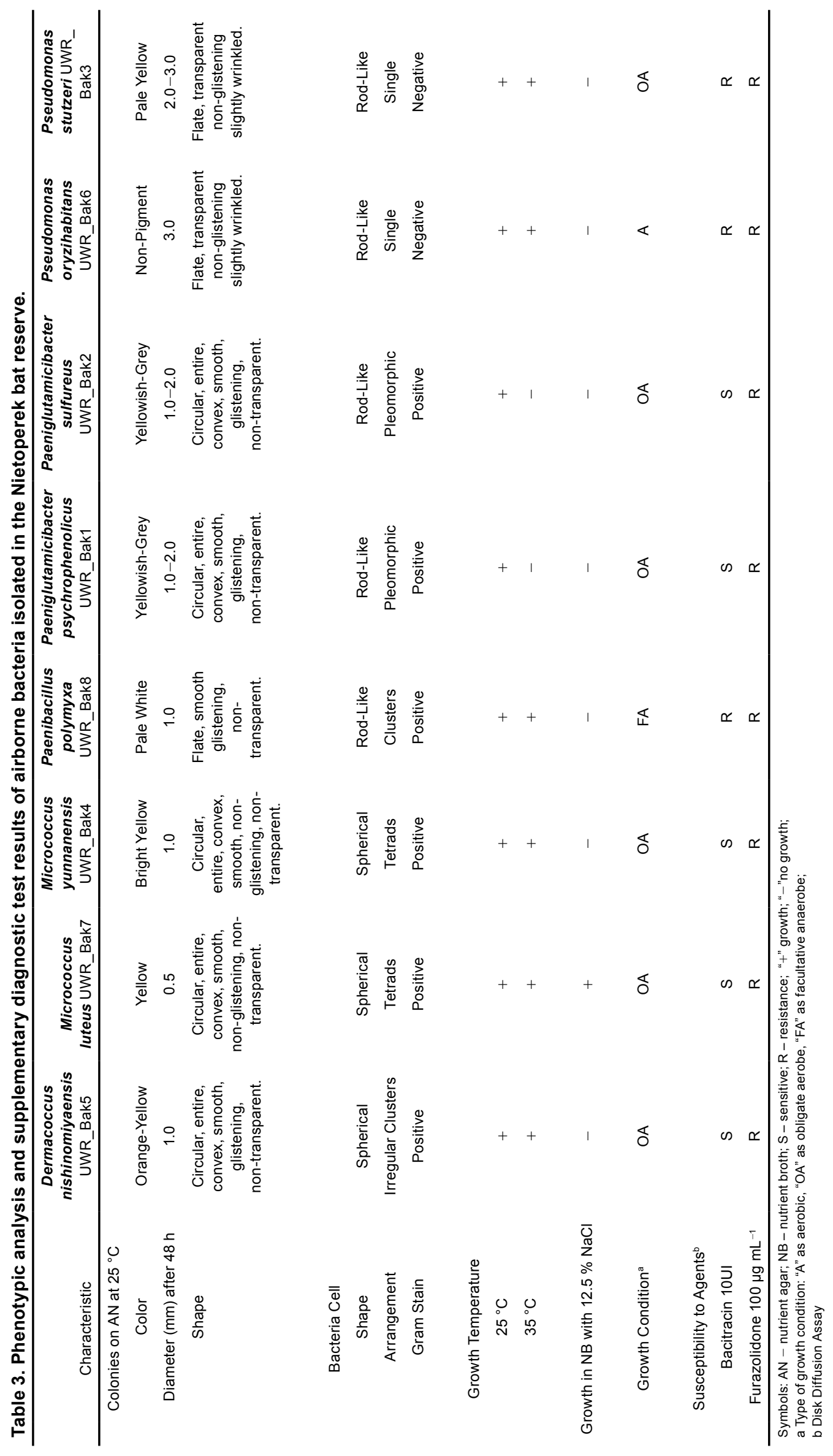




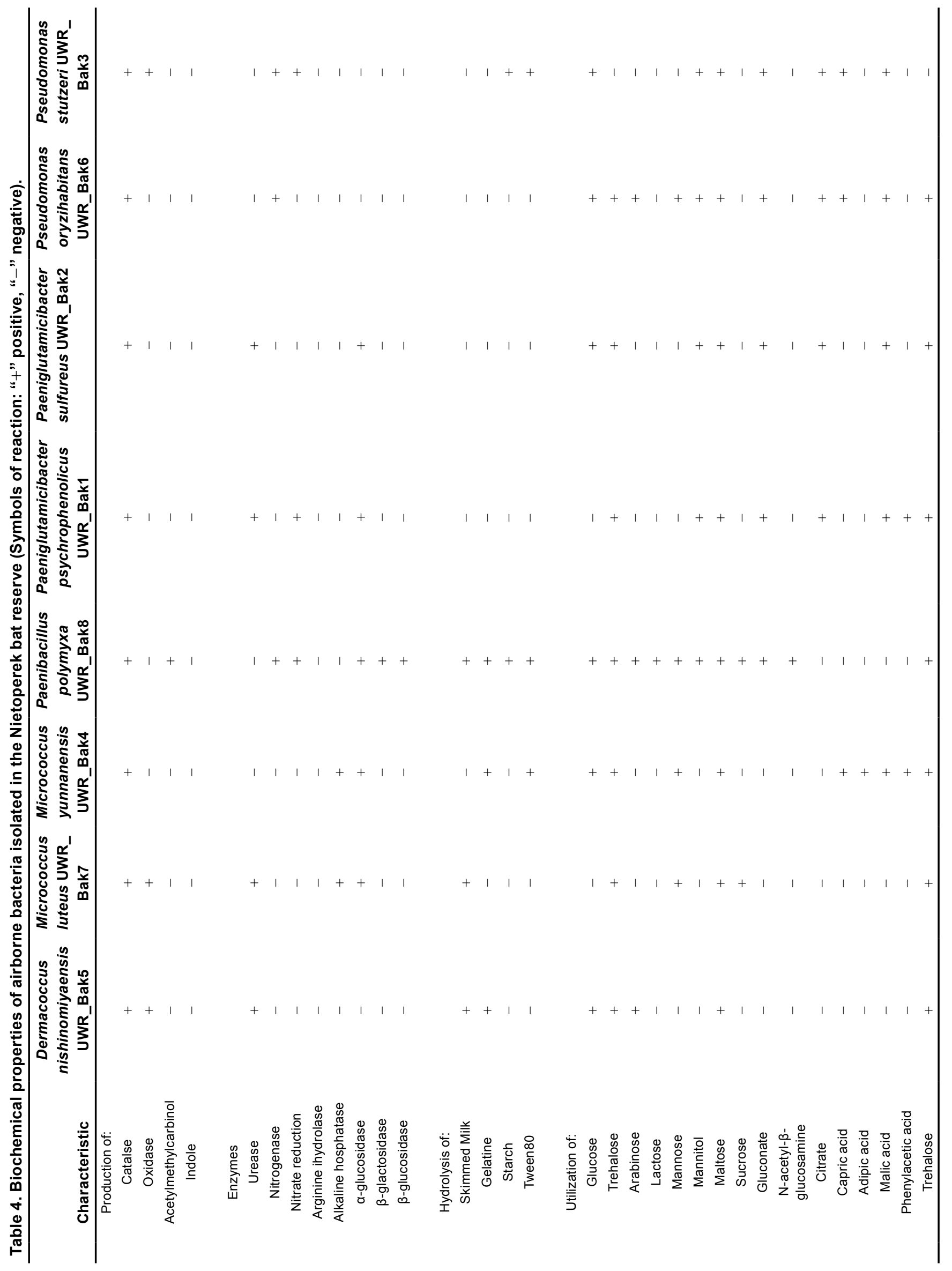


pathogen for humans, however, P. stutzeri infection is rare (Noble and Overman, 1994; Reisler and Blumberg, 1999). Under certain circumstances, these bacterial species could act as potential opportunists affecting the health status of individual bats such as in individuals that are weakened by disease or malnutrition or have been traumatized by martens or cats or during the flight.

\section{Conclusions}

This study is the first that describes cultivable airborne bacteria present in the environment of hibernating bats. Bacterial communities showed differences in terms of composition and abundance among the different parts of the Nietoperek underground corridors, and bacterial growth was dependent on the incubation temperature of samples as well as on the number of bats. Results indicate that indoor air samples contained more propagules of bacteria and more bacterial species than outdoor air samples. Moreover, hibernating bats may be good vectors of bacteria in underground sites because more species of airborne bacteria were isolated from the samples in close vicinity to them. Actinobacteria dominated in this study. Paeniglutamicibacter psychrophenolicus was isolated most frequently from samples incubated at $7^{\circ} \mathrm{C}$, and Micrococcus luteus from samples incubated at $37^{\circ} \mathrm{C}$. Some of the species found in the study can cause opportunistic infections in humans and animals. To better understand the microbial composition and relevance of specific bacteria, further investigations in underground sites could provide more insights into the complex ecosystems and should be regularly performed.

\section{Acknowledgments}

Thanks to Professor Dr. Hab. Gabriela Bugla-Płoskońska from University of Wroclaw (Poland) for the first reading of the manuscript and critical remarks. Research funding was provided by the Ministry of Science and Higher Education carried out by the University of Wroclaw "Grant to Young Researchers". Award Number: 0420/2557/18.

\section{References}

Ash, C., Priest, F.G., and Collins, M.D., 1993, Molecular identification of rRNA group 3 bacilli (Ash, Farrow, Wallbanks and Collins) using a PCR probe test. Proposal for the creation of a new genus Paenibacillus: Antonie van Leeuwenhoek, v. 64, p. 253-260.

Banskar, S., Bhute, S.S., Suryavanshi, M.V., Punekar, S., and Shouchea, Y.S., 2016, Microbiome analysis reveals the abundance of bacterial pathogens in Rousettus leschenaultii guano: Scientific Reports, v. 6, article 36948. http://dx.doi.org/10.1038/srep36948.

Barton, H.A., Taylor, M.R., and Pace, N.R., 2004, Molecular phylogenetic analysis of a bacterial community in an oligotrophic cave environment: Geomicrobiology Journal, v. 21, p. 11-20.

Caruso, F.I., Zuck, M.G., and Bessette, A.E., 1984, Bacterial seedling blight of tomato caused by Bacillus polymyxa: Plant Disease, v. 68, p. 617-620. http://dx.doi.org/10.1094/PD-68-617.

Chelius, M.K., Beresford, G., Horton, H., Quirk, M., Selby, G., Simpson, R.T., Horrocks, R., and Moore, J.C., 2009, Impacts of alterations of organic inputs on the bacterial community within the sediments of Wind Cave, South Dakota, USA: International Journal of Speleology, v. 38 , no. 1, p. 1-10. http://dx.doi.org/10.5038/1827-806X.38.1.1.

Dijksterhuis, J., Sanders, M., Gorris, L.G.M., and Smid, E.J., 1999, Antibiosis plays a role in the context of direct interaction during antagonism of Paenibacillus polymyxa towards Fusarium oxysporum: Journal of Applied Microbiology, v. 86, p. 13-21. http://dx.doi. org/10.1046/j.1365-2672.1999.t01-1-00600.x.

Directive 92/43/EEC (1992) The Conservation of Natural Habitats and of Wild Fauna and Flora, European Commission, 1992, The Habitats Directive, http://ec.europa.eu/environment/nature/legislation/habitatsdirective/index_en.htm [accessed February 18, 2017]

Doyle, J.J., and Doyle, J.L., 1987, A rapid DNA isolation procedure for small quantities of fresh leaf tissue: Phytochemical Bulletin, v. 19 , p. 11-15.

Evans, N.J., Bown, K., Timofte, D., Simpson, V.R., and Birtles, R.J., 2009, Fatal borreliosis in bat caused by relapsing fever spirochete, United Kingdom: Emerging Infectious Diseases, v. 15, p. 1331-1333. http://dx.doi.org/10.3201/eid1508.090475.

Fenton, M.B., 1969, Summer activity of Myotis lucifugus (Chiroptera: Vespertilionidae) at hibernacula in Ontario and Quebec: Canadian Journal of Zoology, v. 47, p. 597-602. https://doi.org/10.1139/z69-103.

Fosse, T., Peloux, Y., Granthil, C., Toga, B., Bertrando, J., and Sethian, M., 1985, Meningitis due to Micrococcus luteus: Infection, v. 13, p. 280-281.

Giacometti, A., Cirioni, O., Quarta, M., Schimizzi, A.M., Del Prete, M.S., and Scalise, G., 1998, Unusual clinical presentation of infection due to Flavimonas oryzihabitans: European Journal of Clinical Microbiology \& Infectious Diseases, v. 17, no. 9, p. 645-648.

Gupta, P., Reddy, G.S.N., Delille, D., and Shivaji, S., 2004, Arthrobacter gangotriensis sp. nov. and Arthrobacter kerguelensis sp. nov. from Antarctica: International Journal of Systematic and Evolutionary Microbiology, v. 54, p. 2375-2378. https://doi.org/10.1099/ijs.0.63110-0.

Hamm, P.S., Caimi, N.A., Northup, D.E., Valdez, E.W., Buecher, D.C., Dunlap, C.A., Labeda, D.P., Lueschow, S., and Porras-Alfaro, A., 2017, Western bats as a reservoir of novel Streptomyces species with antifungal activity: Applied and Environmental Microbiology, v. 83, article e03057-16. https://doi.org/10.1128/AEM.03057-16.

Hoyt, J.R., Cheng, T.L., Langwig, K.E., Hee, M.M., Frick, W.F., and Kilpatrick, A.M., 2015, Bacteria isolated from bats inhibit the growth of Pseudogymnoascus destructans, the causative agent of White-Nose Syndrome: PLOS ONE, v. 10, no. 4, p. e0121329. https://doi.org/10.1371/ journal.pone.0121329.

Jones, G., Jacobs, D.S., Kunz, T.H., Willig, M.R., and Racey P.A., 2009, CarpeNoctem: the importance of bats as bioindicators: Endangered Species Research, v. 8, p. 93-115. https://doi.org/10.3354/esr00182.

Juck, D., Charles, T., Whyte, L.G., and Greer, C.W., 2000, Polyphasic microbial community analysis of petroleum hydrocarbon-contaminated oils from two northern Canadian communities: FEMS Microbiology Ecology, v. 33, p. 241-249. https://doi.org/10.1111/j.1574-6941.2000.tb00746.x.

Jurado, V., Laiz, L., Rodriguez-Nava, V., Boiron, P., Hermosin H., Sanchez-Moral, S., and Saiz-Jimenez, C., 2010, Pathogenic and opportunistic microorganisms in caves: International Journal of Speleology, v. 39, no. 1, p. 15-24. http://dx.doi.org/10.5038/1827-806X.39.1.2.

Kim, Young Soo, Kotnala, B., Kim, Young Ho, and Jeon, Yongho, 2016, Biological characteristics of Paenibacillus polymyxa GBR-1 involved in root rot of stored Korean ginseng: Journal of Ginseng Research, v. 40, p. 453-461. http://dx.doi.org/10.1016/j.jgr.2015.09.003. 
Kocur, M., Páčová, Z., and Martinec, T., 1972, Taxonomic status of Micrococcus luteus (Schroeter 1872) Cohn 1872, and designation of the neotype strain: International Journal of Systematic and Evolutionary Microbiology, v. 22, no. 4, p. 218-223. http://dx.doi.org/10.1099/0020771322-4-218.

Kocur, M., Schleifer, K.H., and Kloos, W.E., 1975, Taxonomic Status of Micrococcus nishinomiyaensis Oda 1935: International Journal of Systematic Bacteriology, v. 25, no. 3, p. 290-293. http://dx.doi.org/10.1099/00207713-25-3-290.

Kodama, K., Kimura, N., and Komagata, K., 1985, Two new species of Pseudomonas: $P$. oryzihabitans isolated from rice paddy and clinical specimens and $P$. Iuteola isolated from clinical specimens: International Journal of Systematic and Evolutionary Microbiology, v. 35, no. 4, p. 467-474. http://dx.doi.org/10.1099/00207713-35-4-467.

Kokurewicz, T., 2004, Sex and age related habitat selection and mass dynamics of Daubenton's bats Myotis daubentonii (Kuhl, 1817) hibernating in natural conditions: Acta Chiropterologica, v. 6, no. 1, p. 121-144. https://doi.org/10.3161/001.006.0110.

Kokurewicz, T., Bongers, F., Ciechanowski, M., Duvergè, L., Glover, A., Haddow, J., Rachwald, A., Rusiński, M., Schmidt, C., Schofield, H., Wawrocka, K., Willems, W., and Zapart, A., 2014, Bat research and conservation in "Nietoperek" bat reserve (Western Poland), in Lina, P.H.C., and Huson, A.M., eds., Abstracts of the XIII European Bat Research Symposium, September 01-05.2014, Šibenik, Croatia: Zagreb, Croatian Speleological Society, pp. 93-94.

Kokurewicz, T., Ogórek, R., Pusz, W., and Matkowski, K., 2016, Bats increase the number of cultivable airborne fungi in the "Nietoperek" bat reserve in western Poland: Microbial Ecology, v. 72, no. 1, p. 36-48. https://doi.org/10.1007/s0024.

Kretzschmar, F., and Heinz, B., 1995, Social behaviour of a large population of Pipistrellus pipistrellus (Schreber, 1774) (Chiroptera: Vespertilionidae) and some other bat species in the mining-system of a limestone quarry near Heidelberg (South West Germany): Myotis International Journal of Bat Research, v. 32-33, p. 221-229.

Kueneman, J.G., Parfrey, L.W., Woodhams, D.C., Archer, H.M., Knight, R., and McKenzie, V.J., 2014, The amphibian skin-associated microbiome across species, space and life history stages: Molecular Ecology, v. 23, p. 1238-1250. https://doi.org/10.1111/mec.12510.

Lalucat, J., Bennasar, A., Bosch, R., García-Valdés, E., and Palleroni, N.J., 2006, Biology of Pseudomonas stutzeri: Microbiology and Molecular Biology Reviews, v. 70, no. 2, p. 510-547. https://doi.org/10.1128/MMBR.00047-05.

Lapage, S.P., Hill, L.R., and Reev, J.D., 1968, Pseudomonas stutzeri in pathological material: Journal of Medical Microbiology, v. 1, p. $195-202$. https://doi.org/10.1099/00222615-1-2-195.

Larsen. A,, Tao, Zhen., Bullard, S.A., and Arias, C.R., 2013, Diversity of the skin microbiota of fishes: evidence for host species specificity: FEMS Microbiology Ecology, v. 85, p. 483-494. https://doi.org/10.1111/1574-6941.12136.

Lin, Rong-Dih, Hsueh, Po-Ren, Chang, Jen-Chyi, Teng, Lee-Jene, Chang, Shan-Chwen, Ho, Shen-Wu, Hsieh, Wei-Chuan, and Luh, Kwen-Tay, 1997, Flavimonas oryzihabitans bacteremia: clinical features and microbiological characteristics of isolates: Clinical Infectious Diseases, v. 24, no. 5, p. 867-873. https://doi.org/10.1093/clinids/24.5.867.

Loveland-Curtze, J., Sheridan, P.P., Gutshall, K.R., and Brenchley, J.E., 1999, Biochemical and phylogenetic analyses of psychrophilic isolates belonging to the Arthrobacter subgroup and description of Arthrobacter psychrolactophilus sp. nov.: Archives of Microbiology, v. 171, p. 355-363. https://doi.org/10.1007/s002030050.

Lucas, K.G., Kiehn, T.E., Sobeck, K.A., Armstrong, D., and Brown, A.E., 1994, Sepsis caused by Flavimonas oryzihabitans: Medicine (Baltimore), v. 73, no. 4, p. 209-214.

Mandal, J., and Brandl, H., 2011, Bioaerosols in indoor environment - A review with special reference to residential and occupational locations: The Open Environmental \& Biological Monitoring Journal, v. 4, p. 83-96. https://doi.org/10.2174/1875040001104010083.

Margesin, R., Schumann, P., Spröer, C., and Gounot, A.-M., 2004, Arthrobacter psychrophenolicus sp. nov., isolated from an alpine ice cave: International Journal of Systematic and Evolutionary Microbiology, v. 54, p. 2067-2072. https://doi.org/10.1099/ijs.0.63124-0.

Marín, M., García de Viedma, D.C., Martín-Rabadán, P., Rodríguez-Créixems, M., and Bouza, E., 2000, Infection of Hickman catheter by Pseudomonas (formerly Flavimonas) oryzihabitans traced to a synthetic bath sponge: Journal of Clinical Microbiology, v. 38, no. 12, p. 4577-4579.

Mickleburgh, S.P., Hutson, A.M., and Racey, P.A., 2002, A review of the global conservation status of bats: Oryx, v. 36, p. 18-34. https://doi. org/10.1017/S0030605302000054

Molinari, L.M., de Oliveira Scoaris, D., Bocchi Pedroso, R., de Lucas Rodrigues Bittencourt, N., Nakamura C.V., Ueda-Nakamura, T., de Abreu Filho, B.A., and Dias Filho, B.P., 2003, Bacterial microflora in the gastrointestinal tract of Nile tilapia, Oreochromis niloticus, cultured in a semi-intensive system: Acta Scientiarum. Biological Sciences, v. 25, no. 2, p. 267-271.

Mühldorfer, K., Wibbelt, G., Haensel, J., Riehm, J.M., and Speck, S., 2010, Yersinia species isolated from bats, Germany: Emerging Infectious Diseases, v. 16, p. 578-580. https://doi.org/10.3201/eid1603.091035.

Noble, R.C., and Overman, S.B., 1994, Pseudomonas stutzeri infection: a review of hospital isolates and a review of the literature: Diagnostic Microbiology and Infectious Disease, v.19, p. 51-56. https://doi.org/10.1016/0732-8893(94)90051-5.

Northup, D.E., Melim, L.A., Spilde, M.N., Hathaway, J.J.M., Garcia, M.G., Moya, M., Stone, F.D., Boston, P.J., Dapkevicius, M.L.N.E., and Riquelme, C., 2011, Lava cave microbial communities within mats and secondary mineral deposits: implications for life detection on other planets: Astrobiology, v. 11, p. 601-618. https://doi.org/10.1089/ast.2010.0562.

Ogórek, R., Kozak, B., Lejman, A., Kalinowska, K., and Dyląg, M., 2012, Analiza genetyczna szczepów Candida albicans za pomocą techniki RFLP-PCR (Molecular typing of Candida albicans isolates using RFLP-PCR): Mikologia Lekarska, v. 9, no. 3, p. 109-114 [in Polish].

Ogórek, R., Pusz, W., Lejman, A., and Uklańska-Pusz, C., 2014, Microclimate effects on number and distribution of fungi in the underground comlex in the Owl Mountains (Góry Sowie), Poland: Journal of Cave and Karst Studies, v. 76, no. 2, p. 146-153. http://dx.doi. org/10.4311/2013MB0123.

Ogórek, R., Dyląg, M., Kozak, B., Višňovská, Z., Tančinová, D., and Lejman, A., 2016a, Fungi isolated and quantified from bat guano and air in Harmanecká and Driny Caves (Slovakia): Journal of Cave and Karst Studies, v. 78, no. 1, p. 41-49. http://dx.doi.org/10.4311/2015MB0108.

Ogórek, R., Višňovská, Z., and Tančinová, D., 2016b, Mycobiota of underground habitats: case study of Harmanecká Cave in Slovakia: Microbial Ecology, v. 71, no. 1, p. 87-99. https://doi.org/10.1007/s00248-015-0686-4.

Pindi, P.K., Manorama, R., Begum, Z., and Shivaji, S., 2010, Arthrobacter antarcticus sp. nov., isolated from an Antarctic marine sediment: International Journal of Systematic and Evolutionary Microbiology, v. 60, p. 2263-2266. https://doi.org/10.1099/ijs.0.012989-0.

Pisarska, K., and Pietr, S.J., 2015, Biodiversity of dominant cultivable endophytic bacteria inhabiting tissues of six different cultivars of Maize (Zea mays L. ssp. mays) cropped under field conditions: Polish Journal of Microbiology, v. 64, no. 2, p. 163-170.

Rampelotto, P.H., 2013, Extremophiles and extreme environments: Life (Basel), v. 3, no. 3, p. 482-485. https://doi.org/10.3390/life3030482.

Rdzanek, M., Pusz, W., Gębarowska, E., and Pląskowska, E., 2015, Airborne bacteria and fungi in a coal mine in Poland: Journal of Cave and Karst Studies, v. 77, no. 3, p. 177-82.

Reisler, B.R., and Blumberg, H., 1999, Community-Acquired Pseudomonas stutzeri vertebral osteomyelitis in a previously healtyh patient: case 
report and review: Clinical Infectious Diseases, v. 29, p. 667-669. https://doi.org/10.1086/598650.

Seldin, L., Silva de Azevedo, F., Alviano, D.S., Alviano, C.S., and de Freire Bastos, M.C., 1999, Inhibitory activity of Paenibacillus polymyxa SCE2 against human pathogenic microorganisms: Letters in Applied Microbiology, v. 28, p. 423-427. https://doi.org/10.1046/j.13652672.1999.00563.x.

Shah, P., Ostwal, K., Jadhav, A., and Shaikh, N., 2015, Post hysterectomy wound infection by Dermacoccus nishinomiyaensis - a first case report in India: European Journal of Biomedical and Pharmaceutical Sciences, v. 2, no. 4, p. 329-335.

Smibert, R.M., and Krieg, N.R., 1994, Phenotypic characterization, in Gerhardt, P., Murray, R.G.E., Wood, W.A., Krieg, N.R., eds., Methods for General and Molecular Bacteriology: Washington, D.C., American Society for Microbiology, pp. 607-654.

Speakman, J.R., and Racey, P.A., 1989, Hibernal ecology of the pipistrelle bat: energy expenditure, water requirements and mass loss, implications for survival and the function of winter emergence flights: Journal of Animal Ecology, v. 58, p. 797-813. https://doi.org/10.2307/5125.

Stella, M., and Suhaimi, M., 2010, Selection of suitable growth medium for free-living diazotrophs isolated from compost: Journal of Tropical Agriculture and Food Science, v. 38, no. 2, p. 211-219.

Stibor, M., Potocky், M., Picková, A., Karasová, P., Russell, N.J., and Králová, B., 2003, Characterization of cold-active dehydrogenases for secondary alcohols and glycerol in psychrotolerant bacteria isolated from Antarctic soil: Enzyme and Microbial Technology, v. 32, p. 532-538. https://doi.org/10.1016/S0141-0229(02)00339-3.

Teixeira, L.C.R.S., Peixoto, R.S., Cury, J.C., Sul, Woo Jun, Pellizari, V.H., Tiedje, J., and Rosado, A.S., 2010, Bacterial diversity in rhizosphere soil from Antarctic vascular plants of Admiralty Bay, maritime Antarctica: The ISME Journal, v. 4, p. 989-1001. https://doi.org/10.1038/ismej.2010.35.

Vanderwolf, K.J., Malloch, D., McAlpine, D.F., and Forbes, G.J., 2013, A world review of fungi, yeasts, and slime molds in caves: International Journal of Speleology, v. 42, no. 1, p. 77-96. http://dx.doi.org/10.5038/1827-806X.42.1.9.

Veikkolainen, V., Vesterinen, E.J., Lilley, T.M., and Pulliainen, A.T., 2014, Bats as reservoir hosts of human bacterial pathogen, Bartonella mayotimonensis: Emerging Infectious Diseases, 20(6), 960-967. http://dx.doi.org/10.3201/eid2006.130956.

Ventura, M., Canchaya, C., Tauch, A., Chandra, G., Fitzgerald, G.F., Chater, K.F., and van Sinderen, D., 2007, Genomics of actinobacteria: tracing the evolutionary history of an ancient phylum: Microbiology and Molecular Biology Reviews, v. 71, no. 3, p. 495-548. http://dx.doi. org/10.1128/MMBR.00005-07.

Verhasselt, B., Claeys, G., Elaichouni, A., Verschraegen, G., Laureys, G., and Vaneechoutte, M., 1995, Case of recurrent Flavimonas oryzihabitans bacteremia associated with an implanted central venous catheter (Port-A-Cath): assessment of clonality by arbitrarily primed PCR: Journal of Clinical Microbiology, v. 33, no. 11, p. 3047-3048.

Vilas, R.A., 2016, Ecological and economical impact of bats on ecosystem: International Journal of Life Sciences, v. 4, no. 3, p. $432-440$.

Weisburg, W.G., Barns, S.M., Pelletier, D.A., and Lane, D.J., 1991, 16S Ribosomal DNA amplification for phylogenetic study: Journal of Bacteriology, v. 173, no. 2, p. 697-703. http://dx.doi.org/10.1128/jb.173.2.697-703.

Woźniak C., 1996, History and architecture of the undergrounds of the Międzyrzecki Rejon Umocniony, in Kokurewicz, T., ed., The Nature of the Gorzow Voyvodeship (1996). Bat reserve "Nietoperek": Gorzow Wielkopolski, Voyvodeship Fund for Environment Protection and Water Management, pp. 78-113.

Zang, Emerson., Brandes, S., Tovar, M., Martin, K., Mech, F., Horbert, P., Henkel, T., Figge, M.T., and Roth, M., 2013, Real-time image processing for label-free enrichment of Actinobacteria cultivated in picolitre droplets: Lab on a Chip, v. 13, p. 3707-3713. http://dx.doi.org/10.1039/ C3LC50572C.

Zhao, Guo-Zhen, Li, Jie, Qin, Sheng, Zhang, Yu-Qin, Zhu, Wen-Yong, Jiang, Cheng-Lin, Xu, Li-Hua, and Li, Wen-Jun, 2009, Micrococcus yunnanensis sp. nov., a novel actinobacterium isolated from surface-sterilized Polyspora axillaries roots: International Journal of Systematic and Evolutionary Microbiology, v. 59, p. 2383-2387. http://dx.doi.org/10.1099/ijs.0.010256-0. 